\title{
Perspectives on university research centers: lessons from the ISBM
}

\author{
Gary L. Lilien ${ }^{1,2,3}$
}

Published online: 3 May 2017

(C) Academy of Marketing Science 2017

V. Kumar's (2017) editorial on the role of university research centers in promoting research and Mike Ahearne's (2017) and Rob Palmatier's (2017) commentaries provide insights on possible roles, organizations and governance structures for university research centers. Kumar (2017) states the role of such centers as follows: "The goal of a research center is to enable interaction between faculty, scholars, students and industry to enhance research opportunities, academic excellence, real world problem solving and knowledge creation and dissemination." This quote cites multiple stakeholders involved in multiple activities, some of which are more valuable for some stakeholders than others, the theme I focus on here.

When Irv Gross, the late Dave Wilson, and I founded the Institute for the Study of Business Markets (ISBM) in 1983, I would have been skeptical that it would still be in existence (and successful) 34 years later in 2017. I would have been more skeptical that I would still be research director.

The longevity of the ISBM suggests that it has continued to serve the needs of some constituents. The mission statement of the ISBM at its founding (and pretty much to this day) was as follows: "The Institute for the Study of Business Markets is an industry-supported center of excellence in the Smeal College of Business at Penn State whose two-fold mission is to (1) Expand research and teaching in business-to-business marketing in academia and to (2) Improve the practice of

Gary L. Lilien

Glilien@psu.edu

1 Smeal College of Business, Penn State University, University Park, PA 16802, USA

2 University of Technology, Sydney, Australia

3 Institute for the Study of Business Markets, Penn State University, University Park, PA 16802, USA business-to-business marketing for member firms in industry." Note two quite different constituencies here.

Seven years after the ISBM was founded, the journal Interfaces published a special issue on models for university-business interaction. I wrote an article for that issue (Lilien 1990) that distilled a number of lessons from the success the ISBM had seen by that time. Those lessons cited the need to acknowledge multiple stakeholders with different values, needs, and resources.

Figure 1 synthesizes much of what I discussed in that article and have learned since. The figure identifies two different sets of stakeholders: academics (including professors and students) and practitioners. Each has assets and needs.

Academics need important problems, understanding of those problems, resources to pursue work on those problems and (in their role as instructors) domain knowledge on which to base their teachings. Assets that academics have include their knowledge of the academic literature, including leading edge research methodology, their extensive networks (if they don't know something, they know whom to ask), their pedagogic skills, and, in many cases, the students they train (as possible employees for practitioners).

Practitioners need answers to important business questions, training in leading edge knowledge and skills, a mechanism to network with other (non-competing) practitioners facing similar problems, and well-trained graduates to hire. Their assets include domain knowledge about real business problems with associated data and the resources needed to address those problems.

Note that Fig. 1 frames the research center as a marketmaker, matching different stakeholders with complementary assets and needs. A successful research center must be constructed so that all stakeholders understand that they are indeed involved in an exchange relationship, that they will be 
Fig. 1 An exchange view of a research center

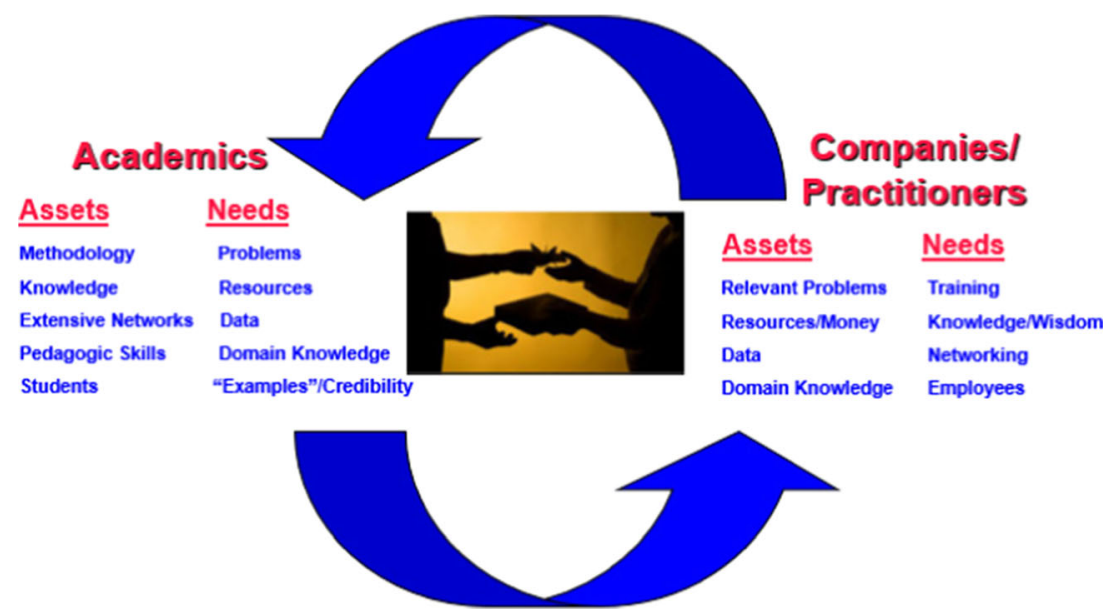

expected to invest in an exchange relationship and that they can expect to see a return on that relationship.

Academics in a research center who obtain access to a problem and data from a firm must do more than say "thank you"; they must provide analysis and insight of business value to the partner-practitioner. One of my academic colleagues says he "consults for data." That means that he provides actionable insights to the firm beyond what the firm can glean itself from the data. In exchange, he gets an understanding of the firm's business problems and access to the associated data for the more rigorous task of crafting an academic article. He always signs an NDA (non-disclosure agreement) that requires the firm's permission to publish any associated work. He says he has never had a problem getting the resulting academic article released after working with the firm to develop a mutually acceptable form of anonymity, sometimes disguising the name of the firm or rescaling the data in a way that substantive findings are not compromised. I have had the same experience.
As in any successful exchange relationship, there can be no winners or losers. The offerings exchanged and the business models of centers may differ, but all successful university research centers focus on ensuring that everyone involved is a winner.

\section{References}

Ahearne, M. (2017). Research centers, business schools, and the world of sales. Journal of the Academy of Marketing Science, 45(4). doi:10.1007/s11747-017-0536-7.

Kumar, V. (2017). The role of university research centers in promoting research. Journal of the Academy of Marketing Science, 45(4). doi:10.1007/s11747-016-0496-3.

Lilien, G. L. (1990). Industry-academic cooperation at Penn State's Institute for the Study of business Markets. Interfaces, 20(6), 94-98.

Palmatier, R. (2017). Marketing research centers: Community, productivity and relevance. Journal of the Academy of Marketing Science, 45(4). doi:10.1007/s11747-017-0538-5. 